\title{
Potential for year-round forage production in Puerto Rico and St. Croix ${ }^{1}$
}

\author{
Thomas R. Sinclair ${ }^{2}$, Yoana C. Newman ${ }^{3}$, \\ María de L. Lugo ${ }^{4}$, Elide Valencia ${ }^{5}$ and Ann R. Blount ${ }^{6}$
}

J. Agric. Univ. P.R. 89(3-4):133-148 (2005)

\begin{abstract}
Forage production can vary substantially during the annual cycle in the tropical islands of Puerto Rico and St. Croix. Cool temperatures, low levels of solar radiation, and low rainfall in December and January have been hypothesized to cause decrease in forage growth. A forage growth model was used to simulate yield in different environments in order to examine these hypotheses quantitatively. Weather data were obtained over a period of three to six years from three locations in Puerto Rico and one location in St. Croix. Minimum temperatures were always near or above $20^{\circ} \mathrm{C}$ and, consequently, did not appear to cause serious losses in forage production. The forage model predicted a decrease in forage production during the winter months due to decreased levels of solar radiation; however, yields were estimated to be approximately 70 to $80 \%$ of summer yields. Whereas shallow rooting depth of $45 \mathrm{~cm}$ could cause decreased yields in some situations, inadequate rainfall could not explain large yield decreases in winter months. This research indicates that a factor in addition to the ones tested contributes to the loss in winter forage yield. It is speculated that short day lengths directly influence the regulation of plant growth such that forage yield is decreased in winter months.
\end{abstract}

Key words: Forage grasses, forage model, weather analysis, precipitation

\section{RESUMEN}

Potencial de producción de forraje durante el año en Puerto Rico y Santa Cruz

La producción de forraje puede variar substancialmente durante el ciclo anual en las islas tropicales de Puerto Rico y Santa Cruz. Se ha hipotetizado que las temperaturas frías, los bajos niveles de radiación solar, y la baja precipitación en diciembre y enero son los causantes de las disminuciones en el crecimiento del forraje. Para examinar cuantitativamente estas hipótesis se utilizó un modelo de crecimiento en forraje para simular el rendimiento bajo diferentes ambientes. Los datos climáticos por un periodo de tres a seis años se obtuvieron para tres localidades en Puerto Rico y una localidad en Santa

${ }^{1}$ Manuscript submitted to the Editorial Board 4 May 2004.

${ }^{2}$ Agronomy Physiology Laboratory, P.O. Box 110965, University of Florida, Gainesville, FL 32611-0965 (Corresponding Author).

${ }^{3}$ Agronomy Department, University of Florida, Gainesville, FL.

${ }^{4}$ Agricultural Experiment Station, University of Puerto Rico, Gurabo Substation.

${ }^{5}$ Agricultural Experiment Station, University of the Virgin Islands, Kingshill, VI. At present: Agricultural Experiment Station, University of Puerto Rico, Mayagüez, P.R.

${ }^{6}$ North Florida Research and Education Center, University of Florida, Marianna, FL. 
Cruz. Las temperaturas mínimas estuvieron siempre cerca o por encima de
los $20^{\circ} \mathrm{C}$; por lo tanto, no parecieron causar serias pérdidas en la producción
de forraje. El modelo de forraje predijo una reducción en la producción de fo-
rraje en los meses de invierno debido a una disminución en los niveles de ra-
diación solar; sin embargo, los rendimientos estimados fueron un 70 a $80 \%$
de los rendimientos del verano. Si bien el enraizamiento superficial a una pro-
fundidad menor de 45 cm podría causar disminución de los rendimientos en
algunas situaciones, la precipitación inadecuada no podría explicar las gran-
des disminuciones ocurridas en los meses de invierno. Esta investigación in-
dica que un factor adicional a los evaluados contribuye a la pérdida en el
rendimiento del forraje durante el invierno. Se especula que la corta duración
del día influye directamente sobre la regulación del crecimiento de la planta
de forma tal que el rendimiento de forraje disminuye en los meses de invierno.

Palabras clave: gramíneas forrajeras, modelo de forraje, análisis climatológico, precipitación

\section{INTRODUCTION}

A major challenge in animal production is year-round supply of feedstuff, especially forage. Just as this problem is obvious in temperate zones, where freezing temperatures inhibit winter forage growth, it also exists in subtropical and tropical regions. Vicente-Chandler et al. (1964) indicated that grass forage yields in Puerto Rico were only about half as great during the months of December through March as in the remainder of the year. They indicated that lower rainfall during this time of year explained part of the yield decrease but suggested that shorter days and cooler weather might also account for decreased growth. Identification of the key environmental factor(s) limiting forage production in the December through March period is critical in guiding research for genetic or management strategies to increase forage yields in subtropical and tropical zones.

More recently, several studies have documented that large variations in both grass and legume forage yields occurred throughout the annual cycle, with noticeable decreases in the period from November through March. Measurements of the growth of seven to twelve grass species at a number of locations in Puerto Rico documented the variation in forage yield throughout the year (Tergas et al., 1988a, b, c, d). These studies indicated decreased growth in the period December through January. Similar results were obtained in other studies in Puerto Rico with forage legumes, including Stylosanthes guianensis (Vélez-Santiago et al., 1981), alfalfa (Medicago sativa) (Tergas et al., 1988e), and perennial peanut (Arachis glabrata) (Ruiz et al., 2000). Annual variation in forage yield was observed despite the fact that in arid locations irrigation was provided to avoid drought stress (Tergas et al., 1988d, e; Ruiz et al., 2000). If water supply was adequate in these experiments, then these results indicated that other environmental factors have been influencing yield during the 'winter' months. 
As originally suggested by Vicente-Chandler et al. (1964), cooler weather and shorter days may explain the decrease in forage yields in December through March. The potential influence of cooler temperature can be investigated through an analysis of the annual variation in temperature and the existence of possible low temperatures that could result in decreased forage growth. There are two components of the hypothesis that shorter days may result in decreased forage production. First, shorter days generally result in less solar radiation, which means decreased light for use in photosynthesis and plant growth. As a consequence, potential mass accumulation by forage plants would necessarily be less during shorter days. Second, shorter day lengths could trigger a direct influence on photoperiod regulation of plant growth so that there is a decrease in forage mass accumulation. This latter hypothesis was recently supported by a study in Florida, USA, where the growth of Pensacola bahiagrass (Paspalum notatum Flugge var. Saurde Parodi) and Tifton 85 bermudagrass (Cynodon spp. L. Pers.) during winter months was constrained by short day lengths (Sinclair et al., 2003). Artificially extending the day length in that field study to 15 $\mathrm{h}$ resulted in major increases in forage production in the winter months.

The objective of this paper is to examine the potential impact of temperature, water availability, and solar radiation on the potential forage yields in St. Croix and Puerto Rico. Individual environmental factors were examined in a forage growth model to assess their impact on forage yield throughout the annual cycle. The approach is similar to that presented by Sinclair et al. (1997) in which a simple mechanistic model of forage growth was used to simulate potential forage production in response to the environment throughout the annual cycle.

\section{MATERIALS AND METHODS}

\section{Meteorological Data and Analysis}

The U.S. National Weather Service records were searched for weather stations in Puerto Rico and U.S. Virgin Islands that reported several years of complete data that included daily minimum and maximum temperature, precipitation, and solar radiation. Adequate data records were identified for St. Croix, U.S. Virgin Islands and for three weather stations in Puerto Rico. The weather station in St. Croix is located at Kingshill $\left(17^{\circ} 42^{\prime} 00^{\prime \prime} \mathrm{N}, 64^{\circ} 48^{\prime} 00^{\prime \prime} \mathrm{W}\right.$ at $45 \mathrm{~m}$ above sea level). Two of the weather stations in Puerto Rico are situated in the eastern portion of the island (Bisley: $18^{\circ} 18^{\prime} 0^{\prime \prime} \mathrm{N}, 65^{\circ} 45^{\prime} 0^{\prime \prime W}$ at $482 \mathrm{~m}$ above sea level; and Río Icacos: $18^{\circ} 16^{\prime} 12^{\prime \prime} \mathrm{N}, 65^{\circ} 46^{\prime} 48^{\prime \prime} \mathrm{W}$ at $600 \mathrm{~m}$ above sea level). The third station represents the northern coastal plain and is located in northwestern Puerto Rico (Isabela: $18^{\circ} 28^{\prime} 12^{\prime \prime} \mathrm{N}, 67^{\circ} 4^{\prime} 12^{\prime \prime} \mathrm{W}$ at $128 \mathrm{~m}$ above sea level). 
Daily observations were obtained from weather stations at St. Croix and Isabela and 15-min records were obtained for Bisley and Río Icacos stations. The 15-min records were transformed into daily values by using SAS basic programming (SAS Institute, Inc., 1996). Seven-day summaries of the data were calculated to facilitate examination of weather variation throughout the annual cycle. Mean values over 7-d intervals were calculated for minimum and maximum temperature and for solar radiation. Total precipitation during the 7 -d intervals was also calculated. Summary weather data were plotted throughout the year for each location (St. Croix, 5 yr; Bisley, 11 yr; Río Icacos, 10 yr; Isabela, 6 yr).

Mean vapor pressure deficit (VPD) was also calculated for 7-d intervals since this variable is particularly important in the calculation of crop transpiration rate. Daily minimum and maximum saturated vapor pressures (VP) were calculated from the respective daily temperatures (TMIN and TMAX) by using the following equations (Sinclair, 1990):

$$
\begin{gathered}
\text { VPmax }=6.107 * \operatorname{EXP}[17.269 * \text { TMAX/(237.3 + TMAX) }] \\
\text { VPmin }=6.107 * \operatorname{EXP}[17.269 * \text { TMIN/ }(237.3+\text { TMIN })] \text { TMAX }
\end{gathered}
$$

An estimate of the daily VPD that is appropriate in the calculation of daily plant transpiration rate is approximately 0.75 of (VPmax -VPmin) (Tanner and Sinclair, 1983). Mean transpirational VPD for 7-d periods was calculated to gauge variations in atmospheric evaporative demand.

Simulations were done by using daily weather records of minimum and maximum temperature, solar radiation, and precipitation. Since there were large lapses in the weather records over several years, only those years in which the data were essentially complete were used in the simulations (St. Croix, 3 yr; Bisley, 3 yr; Río Icacos, 5 yr; Isabela, 6 yr).

\section{Model Analysis}

The forage model was similar to the one developed by Sinclair et al. (1997) for analysis of forage production in Florida. Potential yield was simulated as total possible mass accumulation between harvest intervals. Therefore, it was assumed that the crop intercepted all solar radiation at all times. There was no attempt to simulate lost production during the period of leaf area regrowth following each harvest. Although there is almost certainly a period of less than $100 \%$ radiation interception immediately following harvest, assuming complete radiation interception emphasizes the environmental limitations on crop growth potential rather than plant development. Crop growth was calculated by assuming a potential total solar radiation use efficiency of $0.8 \mathrm{~g} / \mathrm{MJ}$ as also assumed by Sinclair et al. (1997). This value of radiation use efficiency is likely to be somewhat low for a well fertilized C4 crop, but it is a reasonable estimate for many situations of forage production. 
A soil water balance was computed in the model as a basis to restrict growth whenever soil water deficits became limiting to plant mass accumulation. In the model, rainfall was added to the soil and transpired water was removed from the soil on a daily basis. Since we assumed that the crop canopy intercepted all radiation, a corollary assumption was that no solar radiation was received by the soil surface; therefore, soil evaporation could be assumed to be negligible. Crop transpiration rate was calculated by rearranging the expression for transpirational water use efficiency so that transpiration rate $(\mathrm{T})$ was a function of daily mass accumulation (M), atmospheric VPD for transpiration, and a species-specific transpiration efficiency coefficient $(k)$.

$$
\mathrm{T}=\mathrm{M} * \mathrm{VPD} / \mathrm{k}
$$

Daily VPD was calculated from minimum and maximum temperatures as previously described. The transpiration efficiency coefficient was assumed to be $9 \mathrm{~Pa}$, which is appropriate for $\mathrm{C} 4$ species (Tanner and Sinclair, 1983).

A critical variable in the model was the depth of water extraction from the soil. This variable is dependent on plant species and soil physical structure. Rivera et al. (1983) excavated roots of a number of species at the Corozal Experiment Station in Puerto Rico and reported root length density at 15 -cm intervals. Assuming the minimum threshold in root length density for uninhibited water uptake is $1 \mathrm{~cm} / \mathrm{cm}^{3}$ (Gardner, 1960), the depths at which root length density became less than $1 \mathrm{~cm} / \mathrm{cm}^{3}$ in their study were $45 \mathrm{~cm}$ for a species identified as signalgrass (Brachiaria brizantha Hochst. ex A. Rich), $90 \mathrm{~cm}$ for stargrass (Cynodon nlemfuensis), and $150 \mathrm{~cm}$ for guineagrass (Panicum maximum Jacq). Therefore, to simulate the full range of possible rooting depths, simulations were done for rooting depths of 45,90 , and $150 \mathrm{~cm}$. The rooting depth was multiplied by 0.13 (Ratliff et al., 1983) in the model to give estimates of soil water storage capacity for plant extractable water of $58.5,117$, and $195 \mathrm{~mm}$, respectively.

Mass accumulation of forage was inhibited by soil water deficit. The ratio of the amount of current extractable water in the soil, relative to the total extractable water storage capacity, was calculated and used as the variable that could restrict crop mass accumulation. Across species it has been shown that there is little change in plant activity until only about $1 / 3$ of extractable water remains in the soil (Sadras and Milroy, 1996). Since this response has not been measured specifically for forages, the function used in the model to describe this response was one previously used for wheat (Amir and Sinclair, 1991).

Simulations were done for each location and year where the weather data for the entire year included nearly a complete record of daily minimum and maximum temperatures, precipitation, and solar 
radiation. The model was run for each location with each of the assumed soil depths. 'Harvests' were made every $28 \mathrm{~d}$ in the model by resetting the accumulated mass to zero. Consequently, there were 13 'harvests' simulated through the annual cycle in the model.

\section{RESULTS AND DISCUSSION}

\section{Weather Analysis}

The weather data reflected the tropical climate of Puerto Rico and St. Croix, where there is reasonably stable temperature and solar radiation over the annual cycle. Rainfall was more variable than temperature over the annual cycle and among locations. In general, rainfall was somewhat lower in the first part of the year (January through April) than in the rest of the year. In the latter part of the year, often tropical storms resulted in episodes of heavy rainfall.

The weather record for 1995 in St. Croix (Figure 1) illustrates the seasonal pattern described above. The annual variation in temperature was small, only about $5^{\circ} \mathrm{C}$ in both minimum and maximum temperature. The minimum temperature was above $20^{\circ} \mathrm{C}$ except for a brief period in March and the average of minimum and maximum temperature was almost always at or above $25^{\circ} \mathrm{C}$. Since photosynthetic rate of $\mathrm{C} 4$ species is essentially not inhibited until temperature decreases to less than $20^{\circ} \mathrm{C}$ (Long, 1999), it is not likely that the modest temperatures in this case would have a negative impact on forage production.

Solar radiation in St. Croix (Figure 1) showed an annual variation as might be expected with the declination of the sun. There was roughly a $50 \mathrm{MJ} / \mathrm{m}^{2}$ per week variation in average solar radiation between that in winter and that in the early summer months. This variation in solar radiation was simulated to have a direct influence on forage production throughout the annual cycle such that a decrease in forage production was simulated in the winter months.

Rainfall in this example (Figure 1), however, showed dramatic differences through the annual cycle. In this particular year (1995), the rainfall amounts were low in January, and from mid-March through April. The low amounts of rainfall in the early portion of the year would likely allow soil water deficits to develop. Later in the year, however, there were episodes of substantial rainfall as a result of tropical storms.

There was surprisingly little variation in VPD through the year with values generally in the range of 8 to 11 mbars. The stability of VPD reflected the rather consistent difference between minimum and maximum temperatures throughout the year. Consequently, the atmospheric demand for evapotranspiration was stable at a fairly low value throughout the year. 

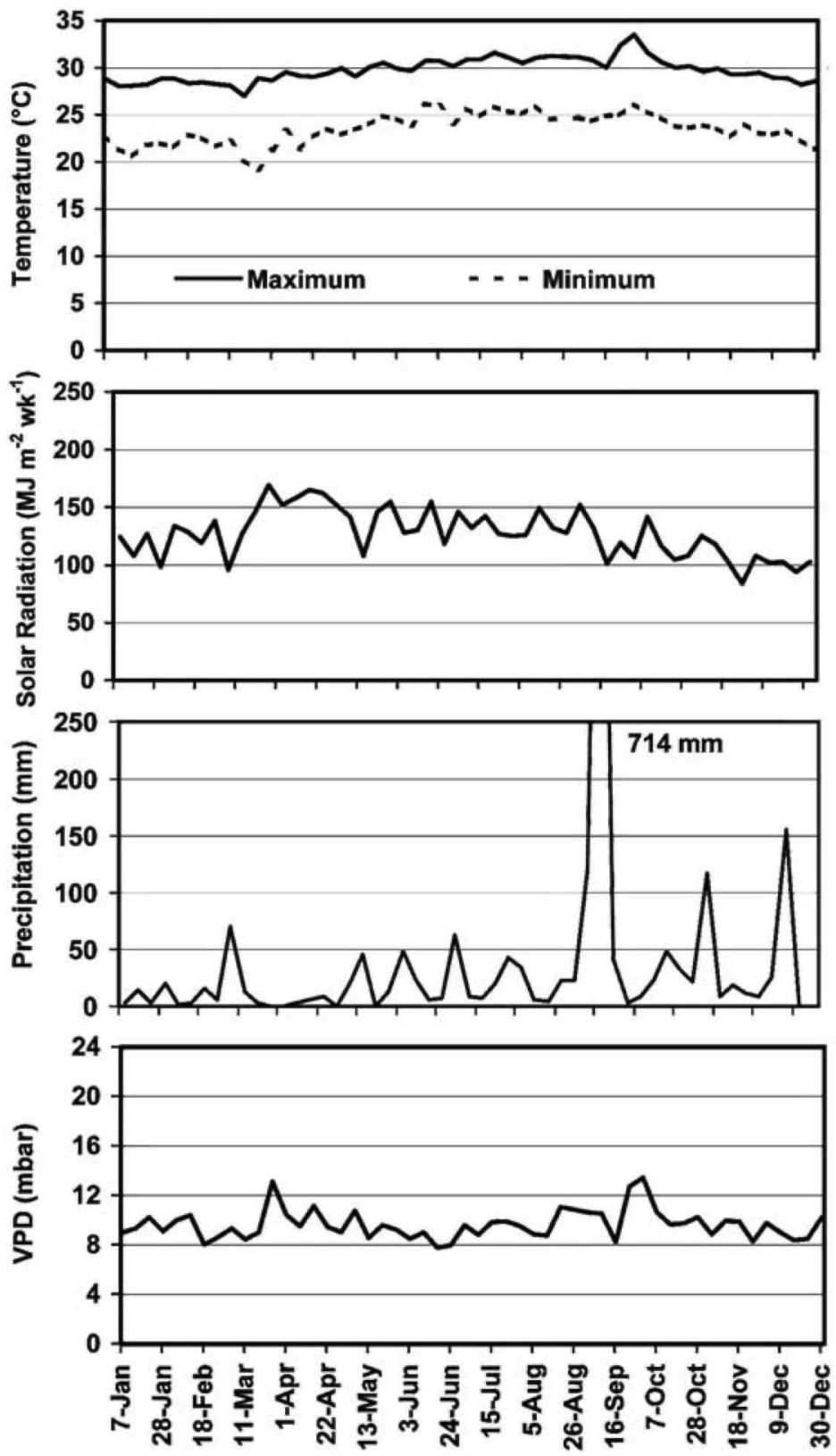

FIGURE 1. Temperature, solar radiation, precipitation, and vapor pressure deficit (VPD) for 7-d intervals during 1995 at Kingshill, St. Croix. 
The weather pattern described above was similar at locations across the northern tier of Puerto Rico. At the eastern end at Bisley, the temperature and solar radiation patterns (Figure 2) were like those of St. Croix. The rainfall pattern, however, was different in that there was more uniform rainfall throughout the year, although the rainfall in January through April was somewhat less than at other times. Vapor pressure deficit was also much lower in Bisley than in St. Croix with most of the values in the 4 to 7 mbar range. The combination of a more uniform rainfall distribution and lower VPD makes it unlikely that severe water deficits would develop.

Slightly southwest of Bisley and at 120-m-higher elevation, the amount of rainfall at Río Icacos was somewhat greater than at Bisley during the year (Figure 3). The minimum temperatures throughout the year at Río Icacos were somewhat lower than at Bisley with average minimum temperatures in the range of 16 to $18^{\circ} \mathrm{C}$ in the winter period. Maximum temperatures were also cooler with the values approximately centered on $25^{\circ} \mathrm{C}$. Still, the changes in temperature through the year were not great and did not appear to be sufficient to result in large decreases in plant photosynthetic rate (Long, 1999). Vapor pressure deficits at Río Icacos were somewhat greater than at Bisley, thus resulting in greater atmospheric demand at Río Icacos for evapotranspiration.

At Isabela (Figure 4), which is located in northwestern Puerto Rico, maximum temperatures were higher and more stable throughout the year than at the other locations. Also, the rainfall pattern in 1995 resembled that in St. Croix with a relatively dry period from January through April. Because of the higher maximum temperature and big difference between minimum and maximum temperatures, VPD at Isabela was greater than that of the other three locations being studied. The combination of comparatively low rainfall and very high VPD makes soil water deficits likely, especially if the soil is shallow.

\section{Model Analysis}

Simulated potential forage growth was calculated to have an annual variation even when soil water was adequate. As illustrated in the St. Croix simulations (Figure 5) when deep rooting was assumed (150 $\mathrm{cm}$ ), annual variations in forage yield were essentially a consequence of variations in solar radiation. The yield of forage in the winter months was simulated to be approximately $75 \%$ of that of the summer months. Consequently, the decreased amount of solar radiation in the winter months is likely to explain a portion of the commonly observed decrease in yields at this time of year. Observed forage yields in the winter, however, are commonly less than half of those in the summer months. Since temperature does not appear to be inhibitory to growth, these results 

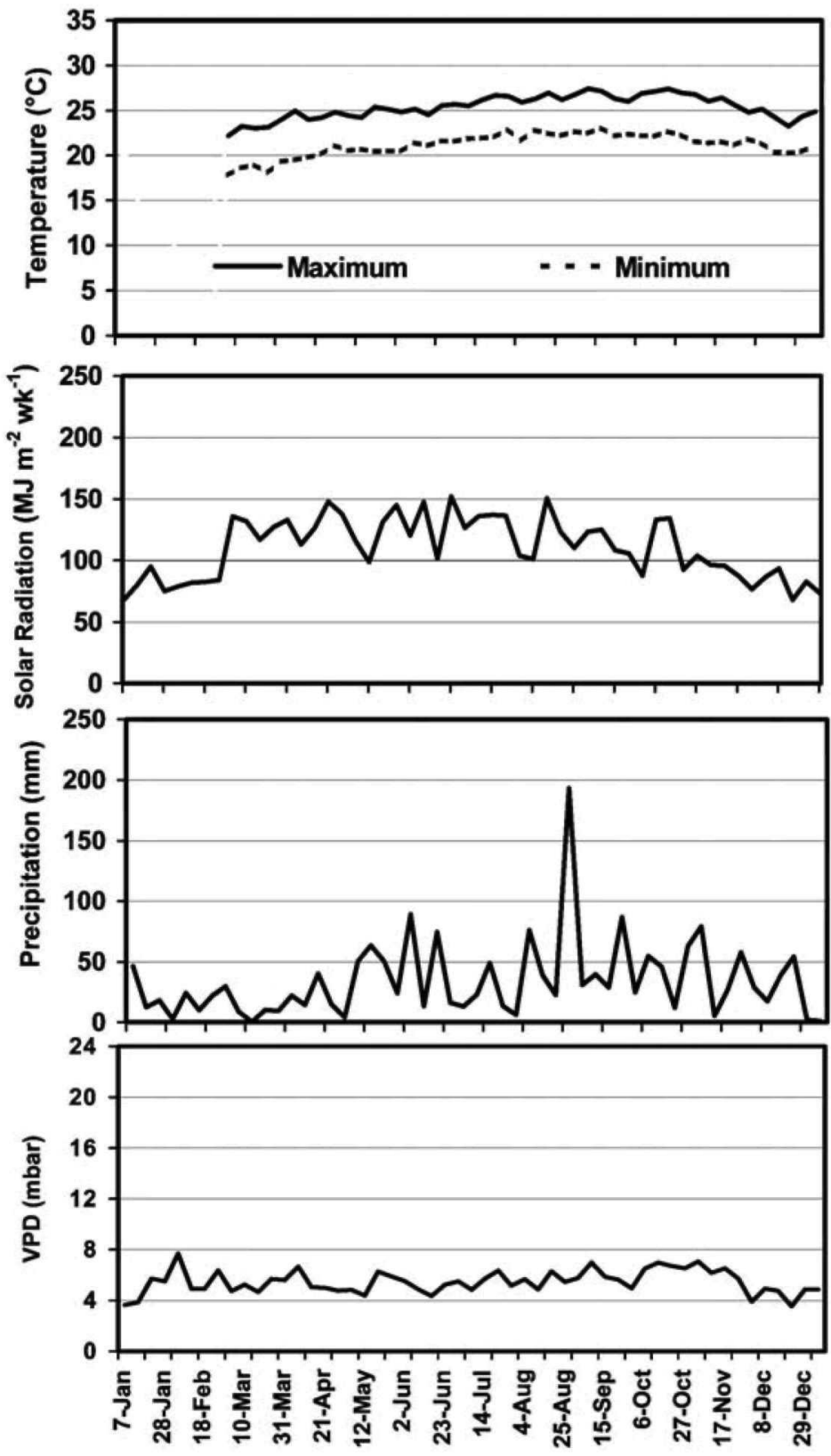

FIGURE 2. Temperature, solar radiation, precipitation, and vapor pressure deficit (VPD) for 7-d intervals during 2000 at Bisley, Puerto Rico. 

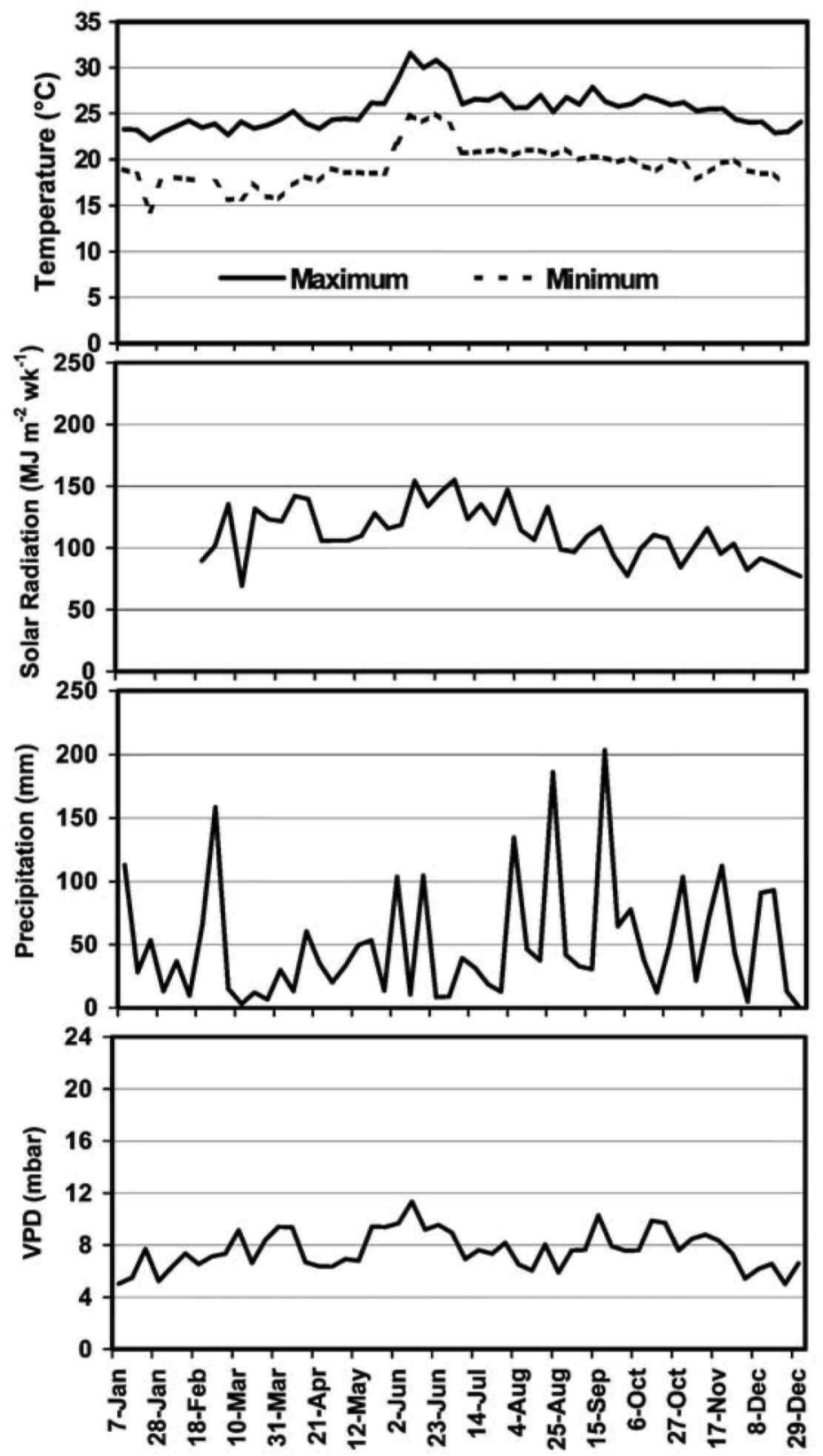

FIGURE 3. Temperature, solar radiation, precipitation, and vapor pressure deficit (VPD) for 7-d intervals during 2000 at Río Icacos, Puerto Rico. 


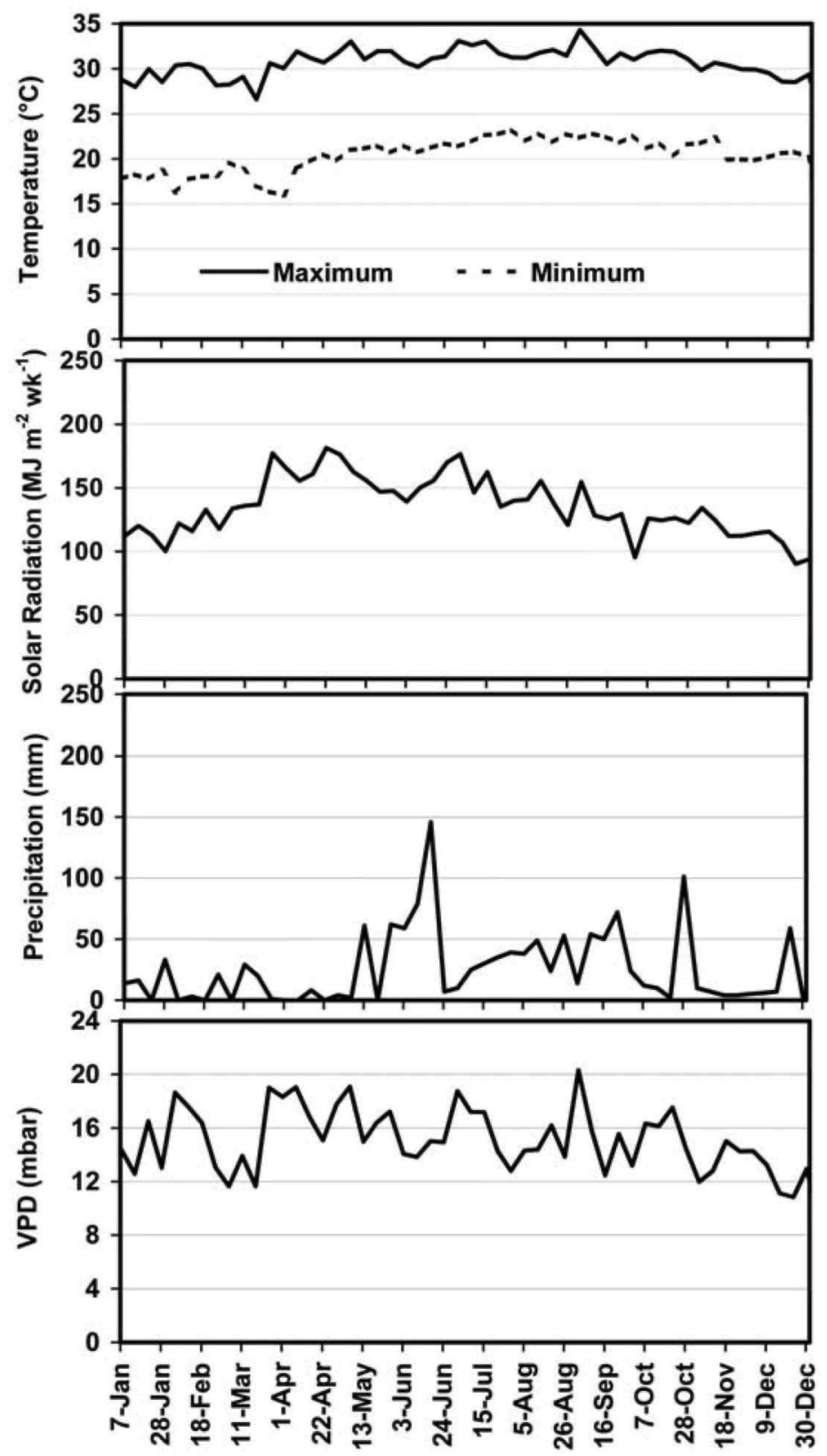

FIGURE 4. Temperature, solar radiation, precipitation, and vapor pressure deficit (VPD) for 7-d intervals during 1995 at Isabela, Puerto Rico. 


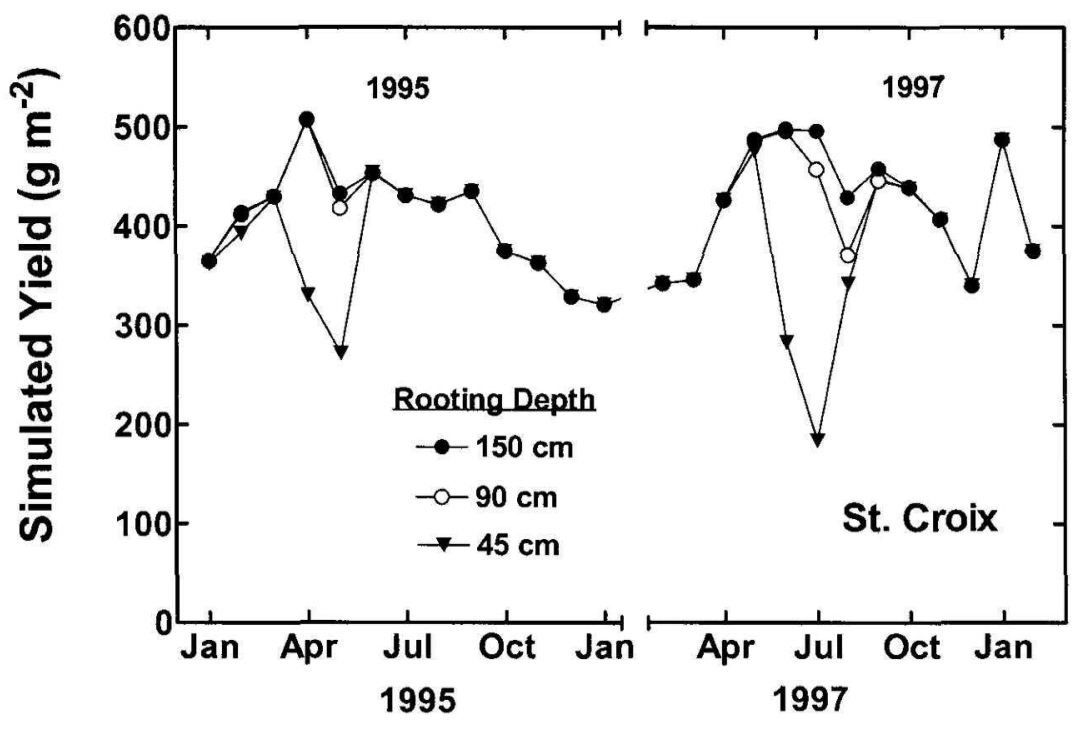

\section{Simulated Harvest Dates}

Figure 5. Simulated forage yield for two years at Kingshill, St. Croix, with assumed rooting depth of 45,90 , or $150 \mathrm{~cm}$.

indicated that plant growth is inhibited by another factor. We hypothesize that plant growth might be a response to direct regulation in the plant triggered by short day lengths.

The dry period in the first part of the year in St. Croix was simulated to have a negative influence on forage yield if rooting depth was shallow. The decrease in yield was especially dramatic for simulations with only a 45-cm rooting depth (Figure 5). Limited soil water storage capacity as a result of a $45-\mathrm{cm}$ rooting depth meant that the soil dried sufficiently to cause large decreases in the photosynthetic activity of the crop. On the other hand, a rooting depth of $90 \mathrm{~cm}$ was generally adequate to prevent yield decreases as a result of water deficits. These results showed the advantage of developing or selecting deeper rooting forages.

As anticipated, low VPD and high rainfall throughout the year at Bisley prevented the development of soil water deficits at any time of the year, even with a rooting depth of only $45 \mathrm{~cm}$ (Figure 6). The annual pattern of forage yield was essentially the same across the three simulated years with the yields in the winter months being about $70 \%$ of that of the summer months. This seasonal variation in yield is again explained as a direct consequence of variation in solar radiation. 
Rainfall amounts at Río Icacos throughout the year were also sufficient to prevent the development of soil water deficits even with a 45$\mathrm{cm}$ rooting depth (Figure 7). The annual variation in simulated forage yield was a result of variation in solar radiation. The annual variation in solar radiation (Figure 3) and yield was not as great as at other locations, and the simulated yield in the winter months at Río Icacos was roughly $80 \%$ of that of the summer months. Consequently, experimental evidence of large decreases in forage yield at this location would provide direct support for the hypothesis that short day lengths are involved in regulation of plant growth capacity.

At Isabela, dry periods in the winter months were simulated to result in substantial decreases in forage yield when rooting depth was only 45 $\mathrm{cm}$ (Figure 8). In 1995, the cumulative effect of low rainfall early in the year (Figure 4) resulted in markedly decreased yields in April and May. Subsequently, rainfall was adequate to recharge the soil and high forage yields were simulated for the remainder of the year. Increasing rooting depth to $90 \mathrm{~cm}$ provided adequate soil water storage in most cases to minimize yield decreases as a result of water deficit (data not shown). In a few cases, including 1995, complete avoidance of water deficit was not achieved, however, unless rooting depth was extended to $150 \mathrm{~cm}$. These

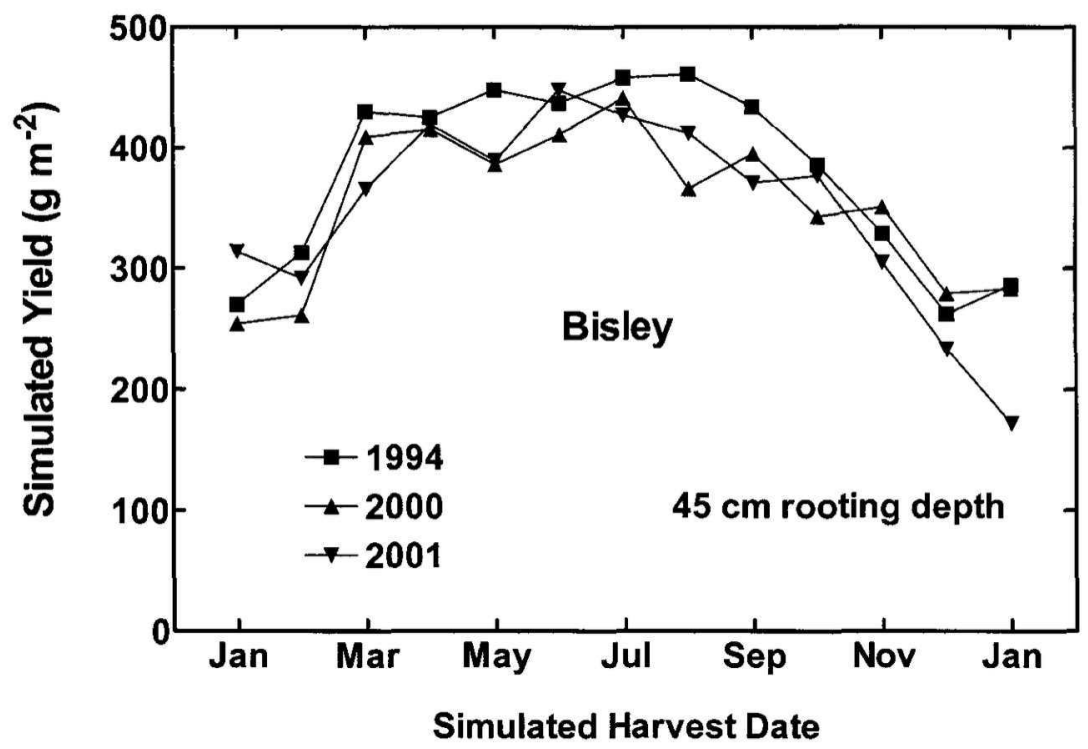

FIGURE 6. Simulated forage yield over three years at Bisley, Puerto Rico, with an assumed rooting depth of $45 \mathrm{~cm}$. 


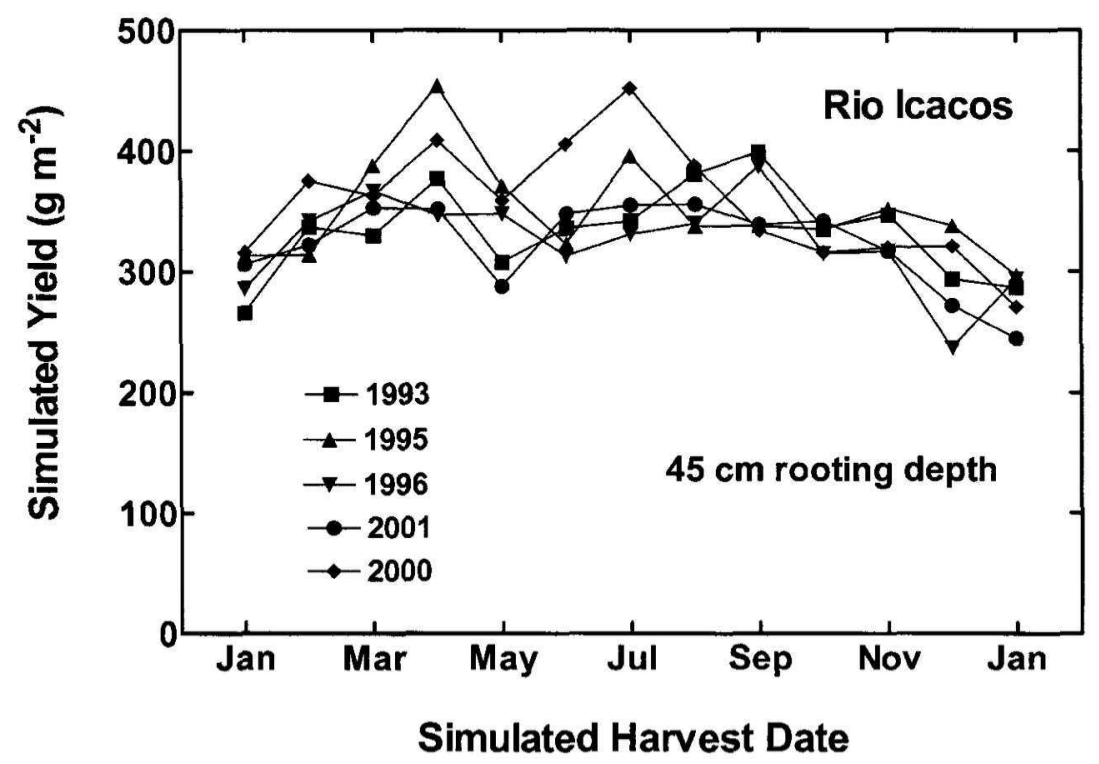

FIGURE 7. Simulated forage yield over five years at Río Icacos, Puerto Rico, with an assumed rooting depth of $45 \mathrm{~cm}$.

results, therefore, indicate that rooting depth might be a significant variable in such a location for increasing year-round forage production.

For simulations with a $150-\mathrm{cm}$ rooting depth at Isabela (data not shown), the annual variation in forage yield was similar to that simulated at other locations. That is, there was a decrease in simulated forage yield in the winter months but the yield in the winter months was still simulated to be about $75 \%$ of that in the summer months.

Large variation in forage production throughout the annual cycle imposes a major restriction on animal production in Puerto Rico and St. Croix, and presumably other tropical areas. Several hypotheses have been offered in the past to explain this variation with the major focus on inadequate rainfall. Colder temperatures and shorter day lengths are also hypothetically involved in causing decreased plant growth. This analysis was undertaken to help resolve these various hypotheses and allow better focus on those specific traits that are limiting forage growth during the winter months.

Analysis of weather data obtained from Puerto Rico and St. Croix indicated that it is unlikely that colder temperature would drastically inhibit forage growth. In these environments, minimum temperatures averaged near or above $20^{\circ} \mathrm{C}$, which is above the threshold for temperature-induced decreases in photosynthetic rates of $\mathrm{C} 4$ species. 


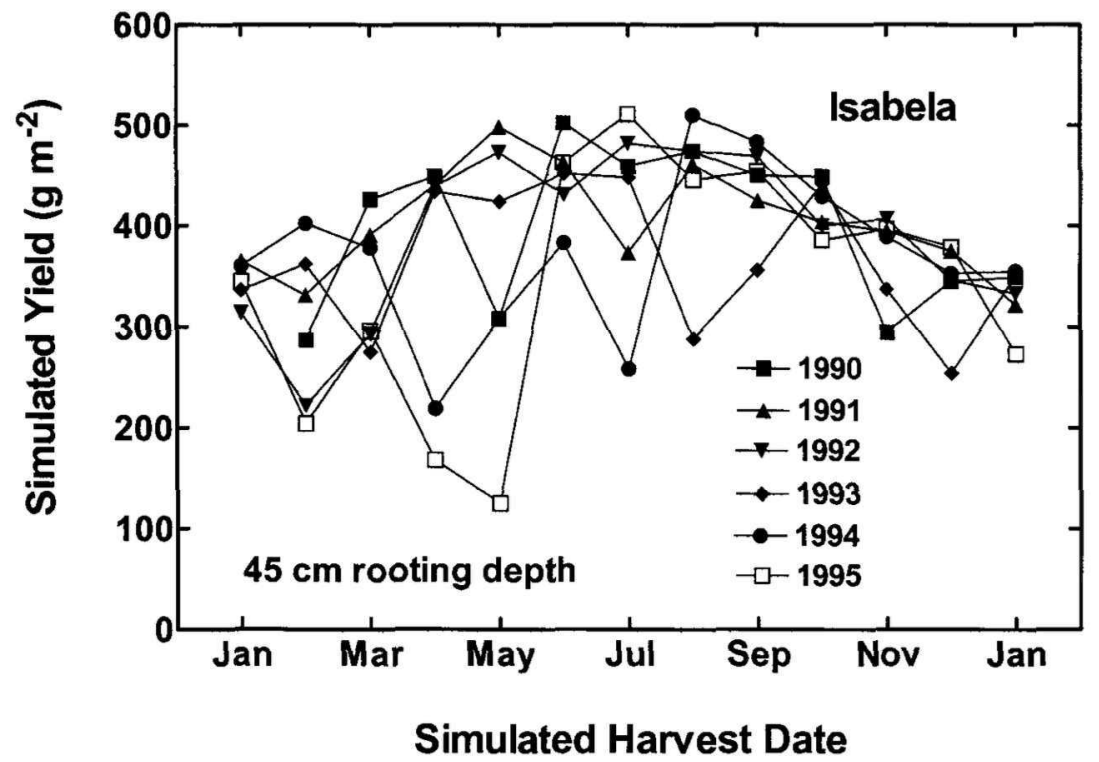

FIGURE 8. Simulated forage yield over six years at Isabela, Puerto Rico, with an assumed rooting depth of $45 \mathrm{~cm}$.

The simulation model indicated that inadequate rainfall in two of the four environments could result in decreased yield when rooting depth of the plants was only $45 \mathrm{~cm}$. Increased rooting depth to $90 \mathrm{~cm}$ was simulated to alleviate the negative consequences of low rainfall on forage yield in most situations. A rooting depth of $150 \mathrm{~cm}$ was simulated to completely eliminate any yield decreases as a result of soil water deficits.

Variation over the annual cycle in the amount of solar radiation received by forage crops was shown to influence simulated yield. The lower solar radiation in the winter months clearly resulted in yield decreases. Winter yield decreases relative to summer yields were simulated to be in the range of 70 to $80 \%$. These yield decreases, however, did not fully account for the loss in winter forage yields that may be less than half the amount of summer yields reported in some publications. The inference from this analysis is that there is another variable in the annual cycle that influences forage yield. The short day length of the winter months resulting in down regulation of plant growth is a prime hypothesis to explain observed yield variations. The dramatic increases in grass growth found in Florida by simply extending the day length (Sinclair et al., 2003) give support to this hypothesis. 


\section{Experimental studies are needed to evaluate the influence of short days on forage growth in these tropical environments.}

\section{LITERATURE CITED}

Amir, J. and T. R. Sinclair, 1991. A model of water limitation on spring wheat growth and yield. Field Crops Res. 28:59-69.

Gardner, W. R., 1960. Dynamic aspects of water availability to plants. Soil Sci. 89:63-73.

Long, S. P., 1999. Environmental responses. pp. 215-249. In: R. F. Sage and R. K. Monson (eds). C 4 Plant Biology. Academic Press, NY.

Ratliff, L. F., J. T. Ritchie and D. K. Cassel, 1983. Field-measured limits of soil water availability as related to laboratory-measured properties. Soil Sci. Soc. Am. J. 47:770-775.

Rivera, E., S. Silva and J. Vicente-Chandler, 1983. Distribution of pigeon peas, cassava, coffee and grass roots in an Ultisol. el. Agric. Univ. P.R. 67:278-285.

Ruiz, T. M., R. Ramos-Santana and A. Sotomayor-Ríos, 2000. Dry matter yield of rhizoma perennial peanut (Arachis glabrata) harvested at six, nine and 12 weeks at two semiarid sites. J.Agric. Univ. P.R. 84:115-131.

Sadras, V. O. and S. P. Milroy, 1996. Soil-water thresholds for the responses of leaf expansion and gas exchange: A review. Field Crops Res. 47:253-266.

SAS Institute, Inc., 1996. SAS/STAT guide for personal computers. Version 8.2. SAS Inst., Cary, NC.

Sinclair, T. R., 1990. Theoretical considerations in the description of evaporation and transpiration. pp. 343-361. In: B. A. Stewart and D. R. Nielsen (eds.) Irrigation of Agricultural Crops. Am. Soc. Agronomy, Madison, WI.

Sinclair, T. R., J. M. Bennett and J. D. Ray, 1997. Environmental limitations to potential forage production during the winter in Florida. Soil Crop Sci. Soc. Fla. Proc. 56:58- 63.

Sinclair, T. R., J. D. Ray, P. Mislevy and L. M. Premazzi, 2003. Growth of subtropical forage grasses under extended photoperiod during short-daylength months. Crop Sci. 43:618-623.

Tanner, C. B. and T. R. Sinclair, 1983. Efficient water use in erop production: Research of re-search? pp. 1-27. In: H. M. Taylor, W. R. Jordan and T. R. Sinclair (eds). Limitations to Efficient Water Use in Crop Production. Am. Soc. Agronomy, Madison, WI.

Tergas, L. E., J. Vélez-Santiago and D. Vera de Saldaña, 1988a. Production of grazed tropical grasses at Toa Baja in the humid northern coastal plains of Puerto Rico. J. Agric. Uniw. P.R. 72:91-98.

Tergas, L. E., J. Vélez-Santiago and D. Vera de Saldaña, 1988b. Production of grazed tropical grasses in different agroecosystems in Puerto Rico: I. Humid mountain. J. Agric. Univ. P.R. 72:99-108.

Tergas, L. E., J. Vélez-Santiago and D. Vera de Saldaña, 1988c. Production of grazed tropical grasses in different agroecosystems in Puerto Rico. II. Humid northern coastal plains. J. Agric. Univ. P.R. 72:201-210.

Tergas, L. E., J. Vélez-Santiago and A. V. Méndez-Cruz, 1988d. Production of grazed tropical grasses in different agroecosystems in Puerto Rico. III. Semiarid. J. Agric. Univ. P.R. 72:211-219.

Tergas, L. E., J. Vélez-Santiago and D. Vera de Saldaña, 1988e. Forage production of nine alfalfa cultivars in the semiarid region of Puerto Rico. J. Agric. Univ. P.R. 72:221-230.

Vélez-Santiago, J., A. Sotomayor-Ríos and M. A. Lugo-López, 1981. Potential of Stylosanthes guianensis as a forage crop in the humid mountain region of Puerto Rico. J. Agric. Univ. P.R. 65:232-240.

Vicente-Chandler, J., R. Caro-Costas, R. W. Pearson, F. Abruña, R. J. Figarella and S. Silva, 1964. The intensive management of tropical forages in Puerto Rico. Bull. 187, Univ. of Puerto Rico, Agricultural Experiment Station, Puerto Rico. 152 pp. 